\title{
THE ACTION OF DECAMETHONIUM IODIDE (C.10) IN MYASTHENIA GRAVIS
}

\author{
BY
}

\author{
H. C. CHURCHILL-DAVIDSON and A. T. RICHARDSON
}

From the Departments of Anaesthetics and of Physical Medicine, St. Thomas's Hospital, London

(RECEIVED FOR PUBLICATION DECEMBER 12, 1951)

Myasthenia gravis is a chronic disease characterized by abnormal fatigue of the voluntary muscles. This fatigue is due to a progressive failure of conduction at the myoneural junction after muscle contraction, and can be temporarily relieved by prostigmine sulphate (Walker, 1934). The exact nature of the neuromuscular block remains obscure, and an analysis of neuromuscular transmission in myasthenia gravis and, in particular, of the quantitative changes in motor end-plate response to acetylcholine are fundamental to the understanding of the disease.

Decamethonium iodide can be considered to have an acetylcholine-like effect on skeletal muscle but differs in not being hydrolysed in the tissues (Paton and Zaimis, 1950).

The Mode of Action of Decamethonium Iodide (C.10)

In 1949 Paton and Zaimis investigated the action of the polymethylene bistrimethylammonium salts and found that the muscular relaxation was maximal in the methonium series when 10 carbon atoms were present in the aliphatic linking chain. Investigation of the decamethonium salts showed that their site of action differed from all the other known muscle relaxants. Fundamentally, these salts act in a way analogous to acetylcholine ; that is, they produce depolarization of the muscle surface membrane in the region of the motor end-plate, and a contraction of the muscle fibres. In the case of decamethonium iodide, however, the muscle fibre remains in a depolarized state for a prolonged period, when it is unable to respond to nerve impulses-a condition of neuromuscular block.

Doses of up to $3 \mathrm{mg}$. were given intravenously to 16 normal conscious volunteers (13 male and three female) and resulted in the development of muscular weakness. The first symptoms in all subjects were visual and occurred in 20 to 30 seconds after the injection. They consisted of strabismus with diplopia and marked ptosis with a feeling of " heavy eyelids". In the majority of cases the diplopia was vertical. The initial symptoms passed off rapidly so that vision had almost returned to normal in five minutes. Inconstantly, a feeling of tightness, particularly in the jaw and calf muscles, was experienced. The second phase of symptoms consisted of muscle weakness starting two to four minutes after the first injection. The neck, trunk, and limb muscles were affected, and, if doses of 3.0 to $3.5 \mathrm{mg}$. were used, a partial loss of voice and a weakening of the swallowing reflex occurred. With such dosages respiration was mildly embarrassed. It was observed that the action of decamethonium iodide was more prolonged in the resting than in the exercised limb.

Paton and Zaimis (1950) have pointed out that in the assessment of the action of decamethonium salts in conscious subjects the potentiating effect of adrenaline must be considered. In our series of normal and myasthenic subjects the same technique has been used on both, and we have no reason to suppose that adrenaline secretion, which increases the stimulant action of decamethonium and changes the pattern of muscle response, has influenced the results of one group more than the other.

\section{Technique}

To measure the effect on muscle power of decamethonium iodide the ulnar nerve was stimulated percutaneously at the elbow or wrist with supramaximal stimuli delivered at a rate of $\mathbf{1 0}$ per second, and muscle action potentials were recorded by skin electrodes from the hypothenar muscles.

The patient was placed on a couch in a position of rest and the 0.3 millisecond stimulus was delivered from an earth-free source. The skin electrodes were placed so as to give an integrated action potential which was used as an index of the number of muscle fibres responding. To detect errors due to any change in position of the skin electrodes, the action potentials were observed both during the paralysing and the recovery phase; the final action potential after recovery was matched with the initial one. The potentials after amplification 


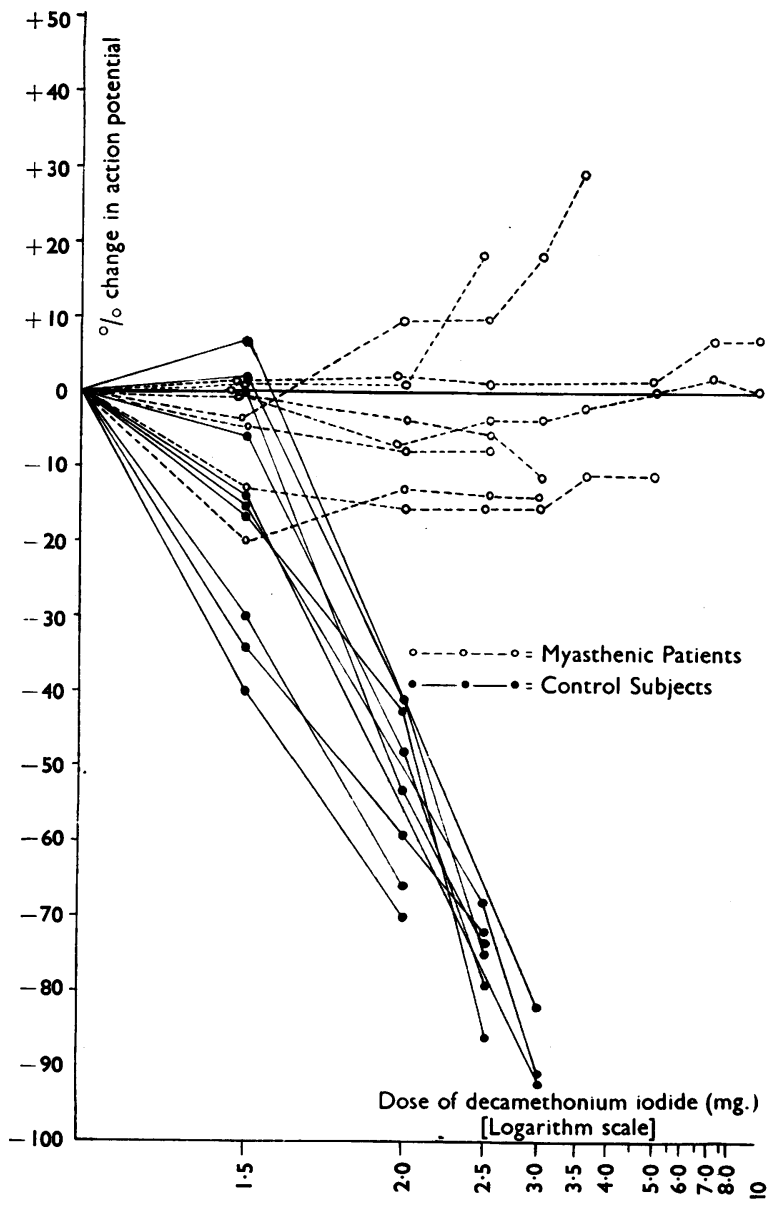

Flg. 1.-Effect of decamethonium iodide on muscle action potential in normal controls and myasthenic subjects.

(time constant of the amplifier, 30 milliseconds) were photographed from a cathode ray oscillograph, the time base of which was triggered by the stimulator. The film was exposed for five seconds every two minutes. allowing 50 stimuli and responses to be recorded on one frame and thus a constant potential wave form was ensured. Peak-to-peak measurements were used as an index of the number of contracting muscle fibres and the results expressed as a percentage change of the initial action potential. No alteration in nerve conduction time or in the duration of the muscle action potential was observed during the experiment.

All drugs were withdrawn from the patient 24 hours before investigation. Each case of myasthenia gravis was fully investigated and the diagnosis confirmed. In these investigations electromyography was used to assess the degree of muscle fatigue and the response to neostigmine. Decamethonium iodide was given into an arm vein in divided doses : an initial dose of $1.5 \mathrm{mg}$., followed in four minutes by $0.5 \mathrm{mg}$.: $0.5 \mathrm{mg}$. was then given at two-minute intervals until a drop of the muscle action potential or clinical muscle weakness occurred.

\section{Results}

Table I shows the effect of intravenous decamethonium iodide on the muscle action potential in 16 controls.

In all patients except one a dose of $2.0 \mathrm{mg}$. resulted in a significant reduction in amplitude of the recorded action potential. In the exception a dose of $2.5 \mathrm{mg}$. produced a significant reduction. The change in the action potential could not be related to the dose per unit of body weight. It will also be seen that in normal subjects doses of 3.0 to 3.5 $\mathrm{mg}$. decamethonium iodide partially paralyse the vocal cords and also abolish the swallowing reflex. In these doses some degree of respiratory embarrassment occurs.

Table II shows the response of 11 cases of myasthenia gravis to intravenous decamethonium iodide.

All except one case showed tolerance in the peripheral muscle examined by the electromyograph. The dosage, however, was in nearly all cases limited by the onset of weakness in the bulbar muscles before the full extent of the peripheral tolerance could be determined. It is of great interest that one case, J.G., was given $10 \mathrm{mg}$. on two separate occasions before and after thymectomy without any effect. In this series seven cases were investigated before and four after thymectomy. The one patient with myasthenia whose peripheral muscles did not show a tolerance to decamethonium iodide was investigated only after thymectomy.

\section{Case Histories}

Case 3.-Miss J. G., aged 20, was admitted to St. Thomas's Hospital in December, 1950, with a history of drooping of both eyelids for four months. Eighteen months previously she had visited her doctor complaining of diplopia, which cleared up. Prostigmine did not appear to have any marked effect on her symptoms although she was improved by ephedrine and relapsed when this was withdrawn. No abnormal fatigue of the peripheral muscles was observed at any time or demonstrated electromyographically. She was given decamethonium iodide on three occasions and was able to tolerate $10 \mathrm{mg}$. without showing any signs of weakness. It is remarkable that she was able to walk normally after this very large dose of the drug. No change in the muscle action potential was observed with $10 \mathrm{mg}$. Thymectomy was carried out in January, 1951, and a thymus weighing $28.5 \mathrm{~g}$. was removed. Since that time she has had no attacks of ptosis or other muscle weakness. She was again given $10 \mathrm{mg}$. of decamethonium iodide in June, 1951, and again it was without effect either clinically or electromyographically. 
TABLE I

CONTROL PATIENTS

\begin{tabular}{|c|c|c|c|c|c|c|c|c|c|c|c|c|c|c|c|c|c|c|}
\hline \multirow[b]{2}{*}{ No. } & \multirow[b]{2}{*}{ Case } & \multirow[b]{2}{*}{$\underset{\text { (kg.) }}{\text { Weight }}$} & \multicolumn{11}{|c|}{$\begin{array}{c}\text { Change }(\%) \text { in Electromyographic Response after Graded Doses of } \\
\text { Decamethonium Iodide }\end{array}$} & \multicolumn{5}{|c|}{ Other Effects } \\
\hline & & & $\begin{array}{l}1 \cdot 5 \\
\mathrm{mg} .\end{array}$ & $\begin{array}{l}2 \cdot 0 \\
\mathrm{mg} .\end{array}$ & $\begin{array}{l}2 \cdot 5 \\
\mathrm{mg} .\end{array}$ & $\begin{array}{l}3 \cdot 0 \\
\mathrm{mg} .\end{array}$ & $\begin{array}{l}3 \cdot 5 \\
\mathrm{mg} .\end{array}$ & $\begin{array}{l}5 \cdot 0 \\
\mathrm{mg} \text {. }\end{array}$ & $\begin{array}{l}6 \cdot 0 \\
\mathrm{mg} .\end{array}$ & $\begin{array}{r}7 \cdot 0 \\
\mathrm{mg} .\end{array}$ & $\begin{array}{r}8 \cdot 0 \\
\mathrm{mg}\end{array}$ & $\begin{array}{l}9 \cdot 0 \\
\mathrm{mg}\end{array}$ & $\begin{array}{l}10 \cdot 0 \\
\mathrm{mg}\end{array}$ & $\begin{array}{l}\text { Dip- } \\
\text { lopia }\end{array}$ & Ptosis & $\begin{array}{l}\text { Muscle } \\
\text { Spasms }\end{array}$ & $\begin{array}{l}\text { Dys- } \\
\text { phagia } \\
\text { Apho- } \\
\text { nia }\end{array}$ & $\begin{array}{l}\text { Respi- } \\
\text { ratory } \\
\text { Em- } \\
\text { barrass- } \\
\text { ment }\end{array}$ \\
\hline 1 & S.C. & 88 & -34 & -59 & -72 & - & -- & - & - & - & - & - & - & + & + & - & - & 一 \\
\hline 2 & D.B. & $66 \cdot 7$ & -40 & -70 & - & - & - & - & - & - & - & - & - & + & + & + & - & - \\
\hline 3 & B.L. & 65 & -30 & -66 & - & - & - & - & - & - & - & - & - & + & + & - & + & - \\
\hline 4 & I.C. & $66 \cdot 2$ & -14 & - & -68 & -90 & $一$ & - & - & - & - & - & - & + & + & + & + & - \\
\hline 5 & E.T. & 69 & -6 & -48 & -82 & - & - & 一 & - & - & - & - & - & + & + & - & - & - \\
\hline 6 & E.J. & 68 & -8 & -10 & -46 & -- & - & - & - & - & - & - & - & + & + & - & - & - \\
\hline 7 & C.M. & 77 & +50 & +20 & -64 & - & - & - & - & - & - & - & - & + & + & + & - & - \\
\hline 8 & A.R. & 70.7 & +2 & -42 & -75 & - & - & - & - & - & - & - & - & + & + & + & - & - \\
\hline 9 & D.M. & 55 & -16 & -40 & -86 & - & - & - & - & -- & - & - & - & + & + & - & + & - \\
\hline 10 & F.M. & 64 & 0 & -52 & -74 & - & - & - & - & - & - & - & - & + & + & + & + & - \\
\hline 11 & H.D. & 70 & +10 & - & -- & -82 & - & - & - & - & - & - & - & - & + & - & + & + \\
\hline 12 & R.B. & 78 & -14 & - & - & -92 & - & - & - & - & - & - & - & - & + & - & + & + \\
\hline 13 & J.R. & 58.5 & - & -82 & - & - & - & - & - & - & - & - & - & + & + & - & + & - \\
\hline 14 & L.T. & - & - & -76 & - & - & - & -- & - & - & - & - & - & + & + & - & - & - \\
\hline 15 & P.J. & $55 \cdot 3$ & - & - & - & - & -94 & - & - & - & - & - & - & - & - & - & - & + \\
\hline 16 & E.F. & $46 \cdot 7$ & -50 & -56 & -64 & - & - & - & - & - & - & - & - & + & + & + & - & - \\
\hline
\end{tabular}

TABLE II

MYASTHENIC PATIENTS

\begin{tabular}{|c|c|c|c|c|c|c|c|c|c|c|c|c|c|c|c|c|c|c|}
\hline \multirow[b]{2}{*}{ No. } & \multirow[b]{2}{*}{ Case } & \multirow[b]{2}{*}{$\underset{\text { (kg.) }}{\text { Weight }}$} & \multicolumn{11}{|c|}{$\begin{array}{c}\text { Change }(\%) \text { in Electromyographic Response after Graded Doses of } \\
\text { Decamethonium Iodide }\end{array}$} & \multicolumn{5}{|c|}{ Other Effects } \\
\hline & & & $\begin{array}{l}1 \cdot 5 \\
\mathrm{mg}\end{array}$ & $\begin{array}{l}2 \cdot 0 \\
\mathrm{mg}\end{array}$ & $\begin{array}{l}2 \cdot 5 \\
\mathrm{mg}\end{array}$ & $\begin{array}{l}3 \cdot 0 \\
\mathrm{mg}\end{array}$ & $\begin{array}{l}3 \cdot 5 \\
\mathrm{mg}\end{array}$ & $\begin{array}{l}5 \cdot 0 \\
\mathrm{mg}\end{array}$ & $\begin{array}{l}6 \cdot 0 \\
\mathrm{mg}\end{array}$ & $\begin{array}{l}7 \cdot 0 \\
\mathrm{mg}\end{array}$ & $\begin{array}{l}8 \cdot 0 \\
\mathrm{mg}\end{array}$ & $\begin{array}{l}9 \cdot 0 \\
\text { mg. }\end{array}$ & $\begin{array}{l}10 \cdot 0 \\
\mathrm{mg}\end{array}$ & $\begin{array}{c}\text { Dip- } \\
\text { lopia }\end{array}$ & Ptosis & $\begin{array}{l}\text { Muscle } \\
\text { Spasms }\end{array}$ & $\begin{array}{l}\text { Dys- } \\
\text { phagia } \\
\text { Apho- } \\
\text { nia }\end{array}$ & 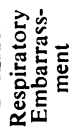 \\
\hline 1 & B.L. & $72 \cdot 6$ & 0 & 0 & +20 & - & 一 & - & 一 & - & - & - & 一 & - & + & - & + & - \\
\hline 2 & E.H. & $65 \cdot 3$ & -4 & - & -- & - & - & -- & 一 & - & - & - & - & - & - & - & + & 一 \\
\hline \multirow[t]{4}{*}{3} & J.G. (i) & $52 \cdot 6$ & -4 & -8 & -8 & - & - & - & - & - & - & - & - & - & - & - & - & - \\
\hline & (ii) & $52 \cdot 6$ & 0 & -4 & -6 & -6 & -6 & -12 & - & - & - & - & - & - & - & - & - & - \\
\hline & (iii) & 52.6 & 0 & -8 & -4 & -4 & -2 & 0 & -4 & +2 & +3 & +5 & 0 & -- & - & - & - & - \\
\hline & (iv) & 52.6 & 0 & 0 & 0 & 0 & 0 & 0 & +6 & +6 & +8 & +8 & +8 & - & - & - & - & - \\
\hline 4 & C.D. & $50 \cdot 8$ & -10 & - & - & - & - & - & - & - & - & - & - & - & - & - & + & - \\
\hline 5 & M.G. & - & -20 & -12 & -13 & -14 & - & - & - & - & - & - & - & - & - & - & + & - \\
\hline 6 & L.M. & 56.7 & -4 & +10 & +10 & +20 & +30 & - & - & - & - & - & - & - & - & - & + & + \\
\hline 7 & B.S. & $63 \cdot 5$ & +20 & +28 & -- & - & - & - & - & - & - & - & - & - & - & - & + & - \\
\hline 8 & R.D. & $70 \cdot 7$ & -32 & -40 & -32 & -28 & -36 & -40 & - & - & -- & - & - & - & - & - & - & - \\
\hline 9 & F.H. & $69 \cdot 8$ & -16 & -16 & -16 & -16 & -12 & -12 & - & - & - & - & - & - & - & - & + & - \\
\hline 10 & A.C. & $64 \cdot 4$ & -10 & -16 & - & - & - & - & - & - & - & - & - & - & - & - & + & - \\
\hline 11 & F.P. & $57 \cdot 1$ & -83 & -1 & - & $-\quad$ & - & - & - & -- & - & - & - & + & - & - & - & - \\
\hline
\end{tabular}


Case 8.-Mr. R. D., aged 30, attended the Out-Patient Department in February, 1951, complaining of drooping of both eyelids for one year. In 1945 he had been under investigation for diplopia and at that time weakness of the left inferior oblique muscle was discovered. On clinical examination in February, 1951, he was found also to have abnormal fatigue of the left tibialis anterior and deltoid. An electromyogram of the left tibialis anterior also showed excessive fatigue. Thymectomy was carried out in April, 1951, and a thymus weighing $23 \mathrm{~g}$. was removed. To date (August, 1951) his condition has not improved. He was given decamethonium iodide in June, 1951, and was able to tolerate $5 \mathrm{mg}$. without any change in the muscle action potential. At this stage, however, the ptosis was worse and he complained of weakness of the legs, worse in the left leg.

It is noteworthy that when weakness occurs in myasthenia gravis after the administration of decamethonium iodide its onset is first in those muscles already rendered weak by the disease. These are generally the bulbar muscles, which appear in myasthenia subjects to be more sensitive than other muscles to decamethonium. This selective action is well illustrated by the onset of weakness in the case of R.D., first in the left log and then later in the normal right leg.

Case 6.-Mr. L. M., aged 41, was first seen in the hospital in November, 1950, with a history of weakness in the arms and legs, ptosis, and dysphagia. At the time of his admission he was taking $35 \mathrm{mg}$. of prostigmine sulphate three times a day, but in spite of this dosage suffered from marked weakness and fatigue, being almost bedridden. Thymectomy was carried out in November, 1949, and a small thymus was removed. His post-operative course was stormy, and respiration was so severely embarrassed that he had to be placed in a Drinker's apparatus for six days. He states that since operation, although he continues to take $30 \mathrm{mg}$. of prostigmine sulphate five times a day, he is now able to do a normal day's work. Electromyographic fatigue tests before and after thymectomy showed excessive fatigue and no apparent change. Decamethonium iodide was administered in June, 1951, and a total of $3.5 \mathrm{mg}$. was given, which, although producing no change in the action potential of the right hypothenar muscles, produced marked weakness of those muscles in which myasthenic fatigue was greatest. This became so severe that a paralysis of swallowing and respiration occurred.

\section{Discussion}

Lanari (1937) and Harvey and Lilienthal (1941) concluded from their experimental work that the muscles of myasthenic patients were hypersensitive to acetylcholine. The latter workers, following Lanari's method, used intra-arterial injections of 20 to $40 \mathrm{mg}$. of acetylcholine into the brachial artery. In myasthenic patients the injection produced a violent contraction of the muscles supplied by the artery, whereas normal subjects experienced only a transitory paralysis (Harvey, Lilienthal, and Talbot, 1941). Wilson and Stoner (1947) completely failed to demonstrate any striking difference between the response of the muscles of myasthenic and normal subjects to acetylcholine. They commented, however, that loss of power, which might be attributed to a depressant level of acetylcholine, was seen more often in normal subjects than in patients with myasthenia gravis. In a more recent contribution Wilson, Maw, and Geoghegan (1951) have failed to find any evidence of increased cholinesterase activity in this condition.

Our results indicate a generalized tolerance of the muscle fibres of myasthenic patients to decamethonium iodide, particularly marked in those patients in whom the only clinical evidence of myasthenia is ptosis and diplopia. However, when the muscle fatigue is more widespread the tolerance is more difficult to demonstrate. For, although it is still marked in the unaffected muscles, it is reduced in those muscles affected by the disease. This resistance to the depolarizing action of decamethonium iodide may be due either to the destruction of the compound before it is able to act on the muscle fibres, or to an inherent resistance of the end-plate of myasthenic muscle fibres to its action.

It is known that with both acetylcholine and decamethonium compounds a stimulatory phase (contraction) precedes the period of muscle paralysis. With decamethonium iodide the stimulatory phase is periodically seen as fascicular twitchings and muscle spasms in the jaw and calf muscles of both myasthenic and normal subjects. With acetylcholine, on the other hand, as this substance is rapidly destroyed, a situation can theoretically arise wherein a blood concentration adequate to bring about depolarization is only momentarily achieved. Thus stimulation of the muscle fibres will occur and the stage of paralysis, which normally follows the stimulatory phase, is so short that it is no longer clinically evident. Similarly, a dose which will produce paralysis in normal muscles may only lead to stimulation in less sensitive muscles, as we believe myasthenic muscle to be. It would therefore appear possible that Harvey and Lilienthal, using 20 to $40 \mathrm{mg}$. of acetylcholine, may have produced a paresis in their normal patients whereas this dosage was only sufficient to produce a stimulatory action in the tolerant muscles of myasthenic patients. Such an interpretation of their work would be compatible with our results and at the same time would be in agreement with the views 
expressed by Wilson and Stoner. Direct evidence of the tolerance of the muscles of myasthenia subjects to acetylcholine is supplied by Buchtal and Engbaek (1948) who found that with small doses $(0 \cdot 2-0.3 \mathrm{mg}$.) of acetylcholine intra-arterially, normal patients showed a motor response (stimulatory phase) whereas myasthenic patients appeared to be tolerant in that no response occurred unless far greater doses were given. Acheson (1944) also found that the muscles of myasthenic patients were a little less sensitive to acetylcholine than those of normal subjects, but stated that the difference was not great on a small number of observations.

\section{Summary}

The effect of intravenous decamethonium iodide on the muscles of 16 normal, control subjects and 11 cases of myasthenia gravis is described. The finding that patients with myasthenia gravis appear to possess a tolerance to this compound is discussed.
We wish to thank Dr. J. St. C. Elkington, Physicianin-Charge of the Neurological Department, and Mr. N. R. Barrett, Surgeon to St. Thomas's Hospital, for permission to investigate cases under their care. It is also a pleasure to acknowledge the help of Dr. Bauwens, Physician-in-Charge, Physical Medicine Department, St. Thomas's Hospital. Miss Jean Davenport rendered valuable secretarial assistance.

\section{REFERENCES}

Acheson, G. H. (1944). J. nerv. ment. Dis., 100, 616.

Buchthal, F., and Engbaek, L. (1948). Acta Psychiat., $K b h ., 23,3$.

Harvey, A. M., and Lilienthal, J. L. (1941). Bull. Johns Hopk. Hosp., 69, 566.

_- _ , and Talbot, S. A. (1941). Ibid., 69, 529.

Lanari, A. (1937). C. R. Soc. Biol., Paris, 126, 827.

Paton, W. D. M., and Zaimis, E. J. (1949). Brit. J. Pharmacol., 4, 381.

- (1.950). Lancet, 2, 568.

Walker, M. B. (1934). Lancet, 1, 1200.

Wilson, A., Maw, G. A., and Geoghegan H. (1951). Quart. J. Med. n.s., 20, 13.

_-, and Stoner, H. B. (1947). Ibid., 16, 237. 